\title{
Product Quality and the International Location of Manufacturing Industry
}

\author{
Sylvia D. Gottschalk \\ University of Sussex
}

\begin{abstract}
This paper investigates how trade liberalisation affects manufacturing production in the South when consumer perception of product substitutability in North and South is asymmetric. Consumers in the former view foreign goods as poorer substitutes of domestic varieties, while in the latter foreign and domestic varieties are equally substitutable. The main result of our exercise is that asymmetric product substitutability gives firms in the North better access to markets in the South. Local manufacturing production then becomes unsustainable even at positive trade costs, while deepening trade liberalisation usually results in the South specialising in non-industrial production.
\end{abstract}

- JEL Classification: F1

- Key Words: trade liberalization, north-south trade, asymmetric product substitutability

\section{Introduction}

Over the last decade, new North-South trade blocs have been created, among them NAFTA and the EU-CEECs trade agreements, allowing firms in the South better access to the larger consumer markets in the North. However, recent research has shown that North-South economic integration may not be followed by increased production of the high quality, high-technology goods favoured by consumers in the North. This idea was first developed by Linder (1961). He argued that consumers in high per capita income countries-the North-may wish to buy

\footnotetext{
*Corresponding address: Sylvia D. Gottschalk, University of Sussex, PG/PH Arts E Building, Falmer, Brighton, BN1 9QH, England. Tel: +44-1273-420626, E-mail: hap59@central.sussex.ac.uk. @ 2002-Center for International Economics, Sejong Institution, All Rights Reserved.
} 
more sophisticated goods, which are more likely to be produced in countries with similar per capita income.

Several models of vertical product differentiation have confirmed the Linder hypothesis. Models of North-South trade in vertically differentiated goods have shown that the North exports high quality varieties while the South produces and exports the low quality varieties (Copeland and Kotwal, 1996, Falvey and Helpman, 1987, Markusen, 1986, Motta and Thisse, 1995). In addition, Falvey and Helpman (1987) show that a product cycle in which the range of goods produced by each country changes over time arise from changes in technology, endowments and income distribution. Products embodying new technologies are conceived and produced in the North, while production of goods nearing obsolescence in the North relocate to the South. An important consequence of specialisation of the South in low quality goods is that trade may break down and hence gains from trade may be inexistant in the South (Copeland and Kotwal, 1996). The South produces low quality goods that are not demanded by highincome Northern consumers, while Southern consumers cannot afford Northern high quality goods. Markusen (1986) obtains similar results with a model of horizontally differentiated products. Motta and Thisse (1995) focus on the role of domestic demand in determining the international success of a firm. They analyse whether a country producing low quality goods can catch up with a country supplying high quality products, given that both have access to the same technology. Their results show that firms in countries where consumers are more willing to pay for better quality products are at an advantage when trade is opened up. On the contrary, countries producing low quality goods in autarky will continue to do so, provided countries are very different in consumers' willingness to pay for better quality product or in their domestic market sizes. Falvey and Kierzkowski (1987) develop a $2 \times 2 \times 2$ model where intra-industry trade is explained by vertical differenciation of products and unequal distribution of income. Consumers demand one type of differentiated good, which is determined uniquely by the consumer's income-given relative prices. A homogeneous, labour-intensive good and a vertically differentiated, capital-intensive good are produced under perfect competition. In addition, the homogeneous good can be produced with distinct technologies. The pattern of inter-industry trade follows the Ricardian-Heckscher-Ohlin predictions. The country producing the homogeneous good more efficiently will export that good and import the differentiated good, while the relatively capital-abundant country exports the differentiated product 
and import the homogeneous good. Intra-industry trade pattern, however, depends on countries' income distribution. Assuming, for instance, that Foreign (Home) country can produce the lowest (highest) quality goods at a lower price. Then, high-income consumers will buy Home country's high-quality goods whereas low income consumers will demand low-quality varieties from Foreign country.

These models assume that quality is explicitely differentiated. However, individuals' perception of quality differentials can be as relevant in their consumption decisions than actual differences. This seems to be particularly the case in industries where superior quality is signaled by brand name, e.g., car, apparel or luxury goods. We thus develop a model of trade liberalisation where consumers determine product quality by the origin of the goods and investigate how these subjective judgements affect countries' industrial specialisation. We build up a $2 \times 2 \times 2$ general equilibrium model following Helpman and Krugman (1985). Countries are distinguished by their relative factor endowments, viz., the South is land-abundant while the North is labour-abundant. Both produce a homogeneous good and have access to the same technology to produce horizontally differentiated manufactures. The North's manufactures are seen as highly differentiated (i.e., low elasticity of substitution) while the South's varieties are viewed as less differentiated (high elasticity of substitution). We conclude that symmmetric product subsitutability gives firms in the North better access to markets in the South, which becomes a manufacture periphery at positive trade costs. Our results are similar those obtained by Amiti (1998). She investigates how country size, transport costs and elasticy differentials between industries affect the location of production. She shows that low elasticity manufacturing production agglomerates in small countries at low trade costs, whereas at intermediate to high trade costs small countries are net exporters of high elasticity manufactures.

The model is presented in section 2, and the equilibrium in open economies is defined in section 3. Section 4 analyses the impact of elasticities differentials on the location of industries and Section 5 concludes.

\section{The Model}

An IRS labour-intensive sector produces horizontally differentiated goods (manufactures) under monopolistic competition. Food is the homogeneous output of the CRS land-intensive and perfectly competitive sector. It is traded at no cost whereas trade in manufactures incurs iceberg type trade costs. The world endow- 
ment of factors of production is divided among 2 countries. Factors of production are perfectly mobile between sectors of production but there is no international factor mobility. We also assume that the production of both goods adjusts instantly to variations of demand caused by the reductions of trade barriers. Finally, no manufactured input is used in the production of final goods.

Product differentiation is modelled here following Dixit and Stiglitz (1977) and the general equilibrium structure follows Helpman and Krugman (1985), which applies the Dixit-Stiglitz-Spence framework to the theory of international trade. Wages and prices are defined as continuous functions of trade costs. These vary continuously from autarky to free trade.

In each country the representative consumer's preferences are given by a homothetic utility function. Its indirect utility function takes the form

$$
V_{i}\left(w_{i}, w_{j}\right)=Y_{i}\left(w_{i}\right) Q_{i}\left(w_{i}, w_{j}, \tau\right)^{-\gamma}
$$

for country $i, i, j=1,2 . Y_{i}$ is the national income and $Q_{i}$ a price index. $g \in[0,1]$ is the fraction of manufactures in the representative consumer's utility. $\tau$ represents transport costs, but not tariffs, although the model could easily incorporate tariffs. It is a symmetric iceberg cost, i.e., a fraction $1-1 / \tau$ of the good "melts" in transit from country $i(j)$ to country $j(i)$. Finally, $\tau$ varies from 1 (free trade) to infinity (autarky).

The price index of a country is a CES-type aggregator with elasticity of substitution $\sigma>1$. This specification follows Dixit and Stiglitz (1977). Here we assume that all varieties have the same elasticity of substitution and that there is a continuum of potential varieties.

$$
Q_{i}(\cdot)^{1-\sigma}=\sum_{j=1}^{2} \int_{v_{j} \in \Omega_{j}}\left(p_{i j}\left(v_{j}, w_{j}\right)^{*} \tau\right)^{(1-\sigma)} d j
$$

for $i=1,2 . p_{i j}(\cdot)=\tau^{*} p_{i}(\cdot)^{2}$ is the price of a variety of manufacture produced in country i and consumed in country $j . p_{i}($.$) is the producer price ex-factory and is$ identical in each country as will be seen in section 2 below. $\mu\left[\Omega_{j}\right]=n_{j}$, i.e., the measure of the set of varieties is the number of firms in country $j$. The set of varieties for each country is the union of the sets of varieties actually produced at each level of trade costs, i.e., $\Omega_{j}=Y_{\tau=1}^{\infty} w_{j, \tau}$.

The demand for manufactures is obtained by Roy's Identity

$$
x_{i}^{d}\left(w_{i}, w_{j}, \tau\right)=\left(p_{j}{ }^{*} \tau\right)^{-\sigma} e_{i} q_{i}(\cdot)^{\sigma-1}
$$


where $e_{i}=\gamma^{*} Y_{i}$ is the total expenditure in manufactures.

In each country agricultural goods are produced according to a Cobb-Douglas production function combining land $(\mathrm{K})$ and labour $(\mathrm{L}), X_{0}=K_{i}^{\varepsilon} L_{i}^{1-\varepsilon}$. The proportion of land in the production of food is $\varepsilon \in(0,5,1)$, since agriculture is land-intensive.

$$
c\left(w_{i}, r_{i}\right)=w_{i}^{1-\varepsilon} r_{i}^{s}=1
$$

Profit maximisation in this perfectly competitive sector yields the equalisation of marginal cost to price. For convenience, the price of agricultural goods is set to 1. $r_{i}$ and $w_{i}$ are the rewards to land and labour respectively. Solving (4) for rewards to land yields $r_{i}\left(w_{i}\right)$.

The production of manufactures in any country is given by

$$
x_{i}\left(w_{i}, w_{j}, \tau\right)=p_{i}^{-\sigma},\left(e_{i}^{*} Q_{\sigma-1}^{s}+e_{j} Q_{j}^{\sigma-1^{*}} \tau\right)
$$

for $i, j=1,2 . e_{i}=\gamma^{*} Y_{i}$ is country's $j$ expenditure in manufactures. As mentioned above, when $i=j$, there is no transaction cost in the consumption of manufactures in which case $\tau=1$.

Manufacturing production is subject to increasing returns to scale and imperfect competition. The first property may be translated in the cost function of a firm producing a single variety of manufactures as follows:

$$
T C_{i}\left(w_{i}, x_{i}\right)=F_{i}(\cdot)^{*}\left(f+m^{*} x_{i}(\cdot)\right)
$$

where $F_{i}()=.r_{i}^{\eta} w_{i}^{1-\eta} f$ and $m \in(0,1)$ are the fixed and marginal costs respectively. $m \in(0,0.5)$ given that manufactures are labour abundant. This cost function is non-homothetic as is generally the case in firms characterised by internal economies of scale.

The profit function for each firm can be written as

$$
\Pi_{i}(.)=\frac{p_{i}^{*} w_{i}}{\sigma}\left(x_{i}(.)-x\right)
$$

where the short-run production level is expression (5) above and the long-run production level is

$$
x=\frac{f^{*}(\sigma-1)}{m}
$$

The long-run production level results from the assumption of free entry and exit 
of firms, which in turn leads to zero profit. Profit maximisation in an imperfect competition sector implies mark-up pricing. So, in each country the producer price is given by:

$$
p_{i}\left(w_{i}\right)=\frac{\sigma^{*} m}{\sigma-1} * w_{i}^{\frac{\varepsilon-\eta}{\varepsilon}}
$$

In each country a unique price can be considered an equilibrium since all firms have identical cost structures ${ }^{3}$. Firms charge (9) independently of the variety they produce. However, in open economies without factor mobility it is not necessarily the case that the international equilibrium price is unique as will be seen in section 3 below.

The demands for factors of production are obtained from Shephard's Lemma:

$$
\begin{gathered}
L_{i}^{d}=\frac{X_{0} *(1-\varepsilon)}{w_{i}}+\frac{n_{i}^{*} F_{i}(\cdot) *(1-\eta)}{w_{i}} *\left(f+m^{*} x_{i}(.)\right) \\
K_{i}^{d}=\frac{X_{0} * \varepsilon}{r_{i}}+\frac{n_{i}^{*} F_{i}(\cdot) * \eta}{r_{i}} *\left(f+m * x_{i}(\cdot)\right)
\end{gathered}
$$

$L_{i}^{s}$ and $K_{i}^{s}$ are country $i$ 's total supply of labour and land respectively, which must equal demand for factors in equilibrium. $n_{i}$ is the measure of the set of varieties produced and will be considered as the number of firms. From these factor market clearing conditions, an expression for $n_{i}$, can be derived,

$$
n_{i}\left(w_{i}\right)=\frac{\varepsilon^{*} L_{i}^{*} w_{i}^{\eta / \varepsilon}-(1-\varepsilon)^{*} K_{i}^{*} w_{i}^{\frac{\eta-1}{\varepsilon}}}{(\varepsilon-\eta)^{*} f^{*} \sigma}
$$

Finally, each country's national income is simply the sum of the rewards of each factor of production and the total profits:

$$
Y_{i}\left(w_{i}\right)=w_{i}^{*} L_{i}+r_{i}\left(w_{i}\right)^{*} K_{i}+n_{i}\left(w_{i}\right)^{*} P_{i}(\cdot)
$$

As will be made explicit in the following section, long-run equilibrium is characterised zero profit, so that total profits in the national income are actually zero.

\section{A. Equilibrium}

Substituting (2), (6), (9), (12) and (13) in (7) yields a non-linear system of 2

\footnotetext{
${ }^{3} \theta\left(w_{i}, x\right)=\frac{T C_{i}\left(w_{i}, x\right) / x}{\partial T C / \partial x}$, where $x$ is the long-run equilibrium output of a single of a single firm. See Helpman and Krugman (1985).
} 
equations to be solved for $w_{i}, i \neq j=1,2$ at distinct values of $\tau$, under the assumption of zero profit.

$$
\begin{gathered}
\Pi_{i}=0 \Rightarrow\left(w_{i}^{\frac{\varepsilon-\eta}{\varepsilon}}\right)^{-\sigma}\left[\frac{e_{i}}{q_{i}^{1-\sigma}}+\frac{e_{j}^{*} t^{1-\sigma}}{q_{j}^{1-\sigma}}\right]-f^{*} \sigma=0 \\
\text { where }^{3} q_{i}=n_{i}^{*}\left(w_{i}^{\frac{\varepsilon-\eta}{\varepsilon}}\right)^{1-\sigma}+n_{j}^{*}\left(w_{j}^{\frac{\varepsilon-\eta}{\varepsilon}}\right)^{1-\sigma} * \tau^{1-\sigma} 7 \\
\text { and } e_{i}\left(w_{i}\right)=\gamma^{*}\left(L_{i}^{*} w_{i}+d^{1 / \varepsilon^{*}} K_{i}^{*} w_{i}^{\frac{\varepsilon-1}{\varepsilon}}\right)
\end{gathered}
$$

The solution of this system will be considered an equilibrium if aggregate profits in each country are zero.

$$
n_{i}^{*} \Pi_{i}=0 \text { with } n_{i} \geq 0 \text { and } \Pi_{i}=0 \text { or } n_{i}=0 \text { and } \Pi_{i} \leq 0
$$

This condition ensures that a country's profits are exhausted by free entry and exit. It also rules out the possibility of the number of firm being negative while each firm's profits are zero. It is clear from (14) that the equilibrium wages and number of firms must be found numerically ${ }^{4}$. The autarky equilibrium wages, which can be found analytically, were naturally chosen as the initial value for wages in the simulations. There are two candidates to equilibrium wage, $w_{i}^{a}$, implying a positive number of firms and $w_{i}^{0}$, which implies no production of manufactures.

In autarky $\tau \rightarrow \infty$, hence $t^{1-\sigma} \rightarrow 0$. (14) is then reduced to:

$$
\frac{e_{i}}{n_{i}}=f^{*} \sigma^{*} w_{i}^{\frac{\varepsilon-\eta}{\varepsilon}}
$$

Substituting the function number of firms (12) and expenditures (15) in the profit function (16) and solving for $w_{i}$ yields $w_{i}^{a}$

$$
w_{i}^{a}=\left[\frac{K_{i}}{L_{i}}\right]^{\varepsilon} *\left[\frac{\gamma+(\varepsilon-\eta)^{-1} *(1-\varepsilon)}{\varepsilon^{*}(\varepsilon-\eta)^{-1}-\gamma}\right]
$$

Alternatively, $w_{i}^{0}$ can be easily obtained from the labour market clearing conditions. Setting (12) to zero and solving for gives

\footnotetext{
${ }^{4}$ The absolute number of firms is actually the measure of the set of varieties and should be interpreted as an infinite number of firms of mass ni.
} 


$$
w_{i}^{0}=\left[\frac{K_{i}}{L_{i}}\right]^{\varepsilon} *\left[\frac{1-\varepsilon}{\varepsilon}\right]^{\varepsilon}
$$

It is worth noting that $w_{i}^{0}$ does not depend on the value of trade costs whereas $w_{i}^{a}$ assumes that trade costs are prohibitive. In autarky (17) satisfies condition (A1), so, both countries produce both goods.

For trade costs in the interval $[1, \infty)$ the values of wages that solve this system, $w_{i}^{*}, i=1,2$, do not necessarily satisfy the condition $n_{i}{ }^{*} \Pi_{i}=0$. When it is not satisfied, it is generally the case that $\Pi_{i}\left(\left(w_{i}^{*}\right) t\right)=0$ but $n_{i}\left(\left(w_{i}^{*}\right) t\right)<0$ at $\tau=t$, $i=1,2$. We then consider that no firm produces manufactures in this country at $=t$ and solve the system

$$
\begin{cases}L_{i}=0 & i=1,2 \\ n_{h}=0 & j \neq 1,2\end{cases}
$$

The result of these simulations will be a graph of the function $w_{i}^{*}(\tau), i=1,2$. Functions of $w_{i}^{*}(\tau)$, e.g., the number of firms, will also be represented by a graph.

\section{Trade Liberalisation and the Location of Industries}

\section{A. Factor Proportions}

Two simulations of the model have been carried out assuming that country 1 is (South) land-abundant and country 2 (North) labour-abundant. First, both countries have similar ${ }^{1}$ relative factor endowments (Case 1). Second, both countries have very dissmilar land-to-labour ratios (Case 2$)^{2}$. The relative factor endowments are $K_{1} / L_{1}=1.11$ and $K_{2} / L_{2}=0.909$ in Case 1 and $K_{1} / L_{1}=2$, and $K_{2} / L_{2}=$ 0.667 in Case 2. Finally, countries are identical in terms of preferences and production structures.

In Case 1, countries's relative factor endowments are inside the Factor Price Equalisation set, as defined in Helpman and Krugman (1985). Consequently, factor prices are equalised at free trade, and, as Figure 1 shows, the relatively land rich country is a net importer of manufactures $\left(n_{1} / n_{2}=0.4\right)$. Case 2 illustrates a situation in which full specialisation and unequal factor rewards result from trade

\footnotetext{
${ }^{1}$ i.e., $K_{1} / L_{1}$ and $K_{2} / L_{2}$ are in the same cone of diversification. Dissimilar relative factor endowments implies $K_{1} / L_{1}$ and $K_{2} / L_{2}$ are in distinct cone of diversification.

${ }^{2}$ We also have simulated the model for $K_{1} / L_{1}=1.667$ and $K_{2} / L_{2}=0.714 ; K_{1} / L_{1}=1.428$ and $K_{2} / K_{2}=$ 0.769 . The results of the simulations for relative wages in country 1 are available on request.
} 
Fig. a: Relative number of firms $(\mathrm{K} 1 / \mathrm{L} 1=1.11$ and $\mathrm{K} 2 / \mathrm{L} 2=0.909)$

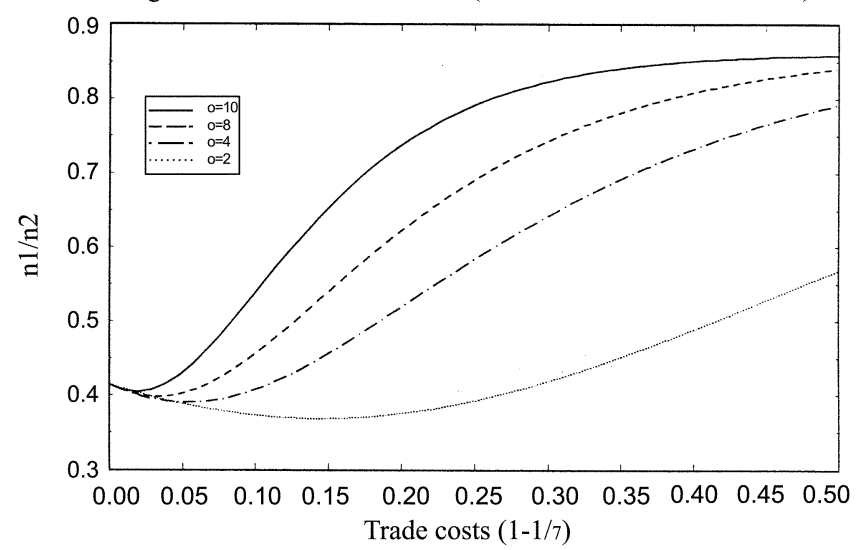

Fig. a: Relative number of firms $(\mathrm{K} 1 / \mathrm{L} 1=2$ and $\mathrm{K} 2 / \mathrm{L} 2=0.667)$

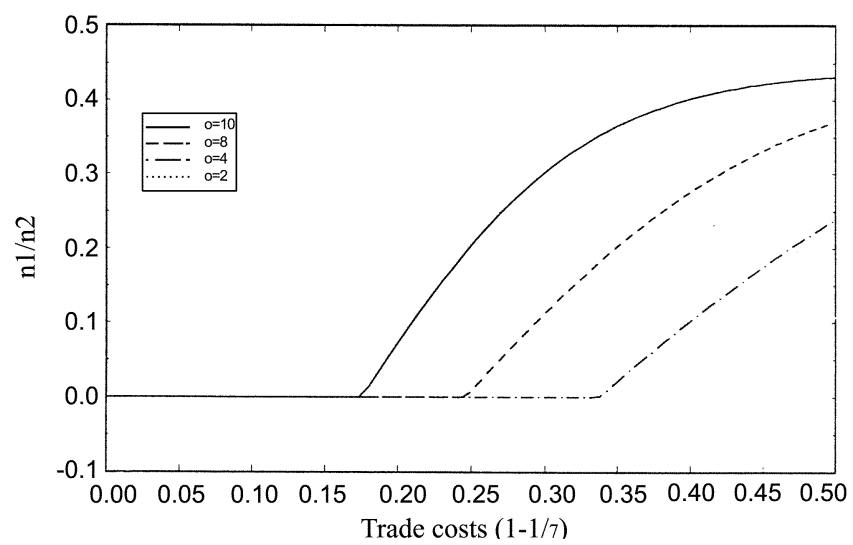

Figure 1. Factor Proportions and Elasticity of Demand

liberalisation. Factor prices are outside the FPE set, and at free trade manufacturing production is concentrated in the North.

The simulations for trade costs varying from autarky to free trade clearly suggest that specialisation occurs when trade is not free (Figure 1b). Since the North has a comparative advantage in manufactures, its manufactures producer prices are lower. At very high trade costs, however, consumers in the South may prefer to demand higher quantities of trade cost free domestic manufactures. As intermediate trade costs, the consumer price of manufactures produced in the North become more competitive. Country 1's consumers demand more quantities of foreign varieties. Firms in country 1 then incur unsustainable losses and cease to produce.

Trade liberalisation does not affect firms in the North as it does the landabundant country, although consumers in the former also reduce their demand for 
local manufactures in order to buy the less competitive varieties produced in the South. Variety-loving consumers demand some of all goods irrespective of their prices. However, the lemph\{quantities\} demanded of each variety depend inversely on its price (equation $\mid \operatorname{ref}\{\operatorname{dem}\}$ ), so that in the North the switch from domestic manufactures to costlier imports is limited. The level of trade costs at which the land-abundant country becomes fully specialised depends on the elasticity of demand, as will be clarified below.

\section{B. Elasticity of Demand and Economies of Scale}

The elasticity of substitution between differentiated goods in the price index (2) and the elasticity of demand in (3) are represented by $\sigma$. An increase in the elasticity of demand reduces each firm's market power -and hence the equilibrium price (9)- and raises the equilibrium output per firm (3). Although price competition is more intense when varieties are viewed as good substitutes (higher $\sigma)$, each firm has a larger market.

Consequently, as trade is opened up firms will face more competition at all levels of trade costs, other things equal, but will rely on a broader market. So, more firms can produce without making losses until trade costs are very low. This can be clearly seen in Figure 1. Irrespective of factor proportions, at any level of trade costs, the number of firms in the South is higher the higher the elasticity of demand. In particular, when countries have dissimilar relative factor endowments (Case 2), country 1 fully specialises in the production of agricultural goods at much lower trade costs. For $\sigma=10$, country 1 does not produce manufactures at trade costs below $17 \%$. The critical level of trade costs at which specialisation occurs increases to $24 \%$ for $\sigma=6,34 \%$ for $\sigma=4$, and $63 \%$ for $\sigma=2$. When country 1 produces both goods down to free trade (Figure 1a), the relative number of firms is also susbtantially lower for $\sigma=2: n_{1} / n_{2}$ varies between $57 \%$ at $50 \%$ trade costs and $41 \%$ at free trade. In contrast, for $\sigma=10, n_{1} / n_{2}=88 \%$ at $50 \%$ trade costs and $41 \%$ at free trade.

The relationship between economies of scale, $\theta$, and elasticity of substitution is given by ${ }^{4}$

$$
\theta\left(w_{i}, x\right)=1+\frac{1}{\sigma-1}
$$

The measure of economies of scale $\theta$ allows us to infer a relationship between market size and the elasticity of demand. A low substitutability of demand implies 
from (19) in high economies of scale. As a result, given the market size, fewer firms will break even. In Case 1 as well as Case 2, there is no straightforward measure of country size, since the absolute factor endowments are not proportional. In case 1 , the absolute amounts of and and labour are $\left(\mathrm{K}_{1}, \mathrm{~L}_{1}\right)=(500,450)$ and $\left(\mathrm{K}_{2}, \mathrm{~L}_{2}\right)=(500,550)$. In case $2,\left(\mathrm{~K}_{1}, \mathrm{~L}_{1}\right)=(500,250)$ and $\left(\mathrm{K}_{2}, \mathrm{~L}_{2}\right)=(500,750)$. Considering, though, that a country has a larger market if it is more endowed of at least one factor, the North is the largest country in both cases. However, comparing country 1's market in Case 1 and Case 2, we can say that its market is larger in Case 1 . As a result, at any $\sigma$ and for any $\sigma$ the relative number of firms in country 1 is higher in Case 1 than in Case 2. For instance, at $50 \%$ trade costs and $\sigma=6$ $n_{1} / n_{2}=84 \%$ in Case 1 against $37 \%$ in Case 2 . At this level of trade barriers, consumers present a strong bias in favour of trade cost free domestic manufactures. So, the difference between the number of firms in South in Case 1 and in Case 2 actually reflects the effects of distinct market size rather than the impacts of factor proportions.

\section{Different Elasticities}

Figure 2a presents the equilibrium relative number of firms for $\mathrm{K}_{1} / \mathrm{L}_{1}=1.11$, and $\mathrm{K}_{2}, \mathrm{~L}_{2}=0.909$ assuming that countries differ in their elasticities of demand. It is assumed that the land-abundant country's elasticity of demand equals 10 while the elasticity of demand of the labour-abundant country is first set to 4 (Case 1a) and then increased to 6 (Case 1b). In both cases, the goods produced in the North are viewed as poor substitutes to each other and, more importantly, to varieties produced in the South.

When both countries produce goods equally substitutable $(\sigma=10, i=1,2)$ the relative number of firms in country 1 is at its highest, varying between $86 \%$ and $43 \%$ (Fig. 1a). In contrast, when consumers in country 2 view foreign manufactures as poorer substitutes of domestic varieties, the relative number of firms in country 1 only reaches $50 \%\left(\sigma_{2}=6\right)$ or less than $25 \%\left(\sigma_{2}=4\right)$ at $50 \%$ trade costs. At free trade country 1 is either fully specialised in agricultural goods $((2=4)$ or produces a minimum of manufactures $\left(\sigma_{2}=6\right)$. Although the results are quite robust to changes in the initial values of wages, it is not possible to rule out full specialisation when $\sigma_{1}=10, \sigma_{2}=6$.

The contrast between the behaviour of manufacturing production in Case 1 and Case 1a-1b can only be explained by the disparity of the elasticity of demand. Factor proportions play a secondary role, since they are identical in all Cases. 
Fig. a: Relative number of firms $(\mathrm{K} 1 / \mathrm{L} 1=1.11$ and $\mathrm{K} 2 / \mathrm{L} 2=0.909)$

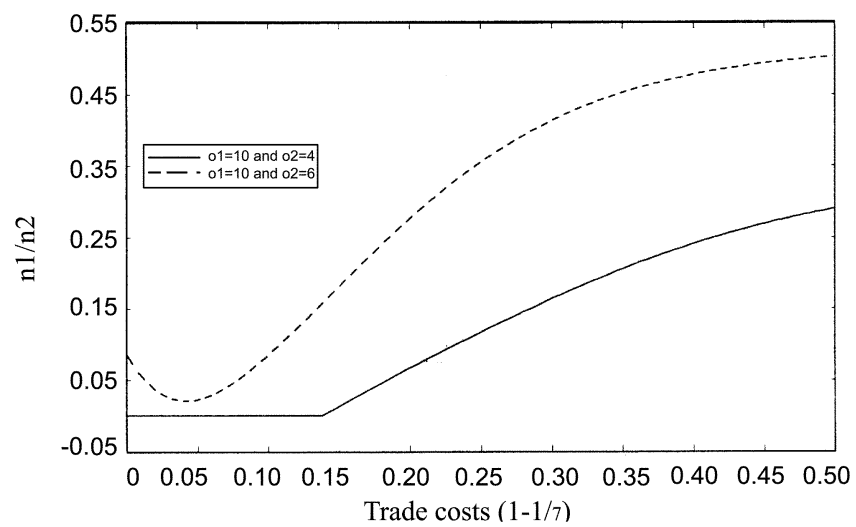

Fig. b: Social welfare $(\mathrm{K} 1 / \mathrm{L} 1=1.11$ and $\mathrm{K} 2 / \mathrm{L} 2=0.909)$

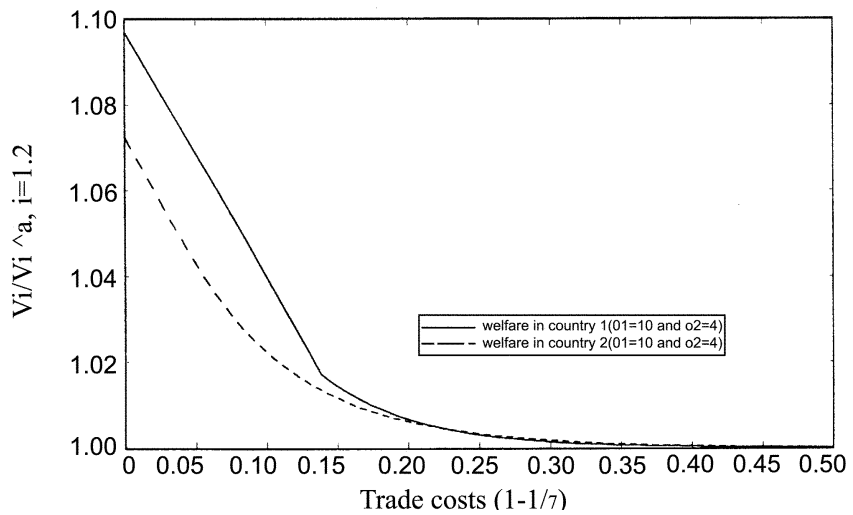

Figure 2. Different Elasticities of Demand

First, as consumers in the North tend to prefer specific goods (low $\sigma$ ), opening up to trade does not translate into increased demand for foreign goods. On the other hand, consumers in the South are less particular (high $\sigma$ ) and demand increased quantities of imported manufactures. This asymmetry in consumer behaviour is to the advantage of firms in the North. These firms have a better access to market in the South than firms in the South to foreign markets.

Furthermore, the North's favourable factor endowments implies that its production costs of manufactures are lower. Hence, its exports are more competitive in the South at intermediate and low trade costs. At high trade costs, e.g., 50\%, domestic market bias is stronger in any country than price conside-rations. This allows firms in the North to stand the stiffer price competition in the South. As was seen above, higher elasticity of demand is associated with lower mark-up, i.e., lower prices. Finally, intense product competition in the South implies a lower 
number of firms (expression (12)). In Case 2, the absolute number of firms ${ }^{5}$ in autarky is $n_{1}=2.78, n_{2}=8.088\left(\sigma_{2}=4\right), \mathrm{n}_{2}=5.39\left(\sigma_{2}=6\right)$. The size of the South's manufacture industry is thus limited when compared with industry in the North. Since individual firms in the South have a reduced market in the North and face more intense competition from foreign firms in their domestic market, the manufacture industry in the South shrinks as economic integration deepens. At low trade cost, $14 \%$, the South ceases to produce manufactures altogether.

\section{Welfare}

Full specialisation of the South is not necessarily associated with declining social welfare, as Figure $2 \mathrm{~b}$ illustrates. Trade liberalisation allows consumers to have access to more varieties, which increases their welfare. Furthermore, as the North produces manufactures at lower costs, its varieties are available to consumers in the South at more competitive price than domestic varieties. Social welfare in the South is consistently above autarky levels $\left(V_{1} / V_{1}^{a}>1\right)$, and most of the gains from trade are reaped after the country has fully specialised. For instance, when $\sigma_{1}=10$ and $\sigma_{2}=4$ country 1 specialises at $14 \%$ trade costs. For trade costs above this critical level, the gains from trade amount to $1.7 \%$, against $8 \%$ after specialisation. When $\sigma_{1}=10, \sigma_{2}=6$ total gains from trade reach $7.2 \%$ at free trade. Product competition and inefficient use of scarce factors account for the lower gains from trade in this case. First, since country 1 does not specialise in the production of the goods it can produce efficiently, viz. food, scarce factors are being used to produce manufactures inefficiently. This translates into a higher price index (2), when compared with the price index resulting from full specialisation. Second, product competition in country is more intense when $\sigma_{2}=6$, reducing the equilibrium number of firms and consequently the number of varieties available.

\section{Conclusion}

In this paper we show that North-South economic integration may lead to the full specialisation of the South in agricultural production, even though North and South produce manufactures of identical qualities. If consumers in the North view manufactures produced in the South as poorer substitutes of their domestic varieties, while goods are equally substitutable in the South, the market of firms in the North expands to a much greater extent than the market of their competitors in 
the South. If the manufacture industry in the North is more efficient, e.g., due to favourable relative factor endowments or better technology, industrial production becomes unsustainable in the South.

Date accepted: May 2001

\section{References}

Allgower, E. and K Georg (1990), Numerical continuation methods: An introduction, Springer Series in Computational Mathematics, Springer Verlag.

Amiti, M.(1998) Inter-industry trade: Does country size matter?, Journal of International Economics, vol.44, 2, pp.231-55.

Beath, J. and Y. Kastoulacos (1991), The economic theory of product differentiation, Cambridge University press, Cambridge.

Copeland, B. and A. Kotwal (1996), Product quality and the theory of comparative advantage, European Economic Review, 40 (1996), 1745-1760

Dixit, A. and Stiglitz, J.E. (1977), Monopolistic competition and optimum product diversity, American Economic Review, vol.67, 3, pp.297-308.

Falvey, R. and H. Kierzkowsky (1987), Product quality, intra-industry trade and (im)perfect competition, in Protection and competition in international trade, ed. by H. Kierzkowsky. Basil Blackwell.

Flam, H. and E. Helpman (1987), 'Vertical product differentiation and North-South trade', American Economic Review, 77(5), 810-23.

Helpman, E. and P. Krugman (1985), Market structure and foreign trade, MIT Press, Cambridge, Mass. Sixth edn.

Judd, K.L. (1998), Numerical Methods in Economics, MIT Press, Cambridge, Mass.

Linder, S. (1961), An essay on trade and transformation, Almqvist and Wiksell, Stockholm.

Markusen, J. (1986), 'Explaining the volume of trade', American Economic Review, 76, 1002-1011.

Motta, M. and J-F. Thisse (1995), 'On the persistence of leadership in international trade', CEPR Discussion Paper Series 1106. 